\title{
On editing the reception of Pliny's Natural History
}

\author{
Cynthia Damon
}

\section{Pathways}

Editing texts is an enterprise that may be compared to pathways connecting discrete and sometimes distant entities: the editor and the text of course, but also, I submit, scholarly generations and fields. ${ }^{.}$As the exemplary projects undertaken in the course of the Ars edendi program have shown, editorial methods are extremely heterogeneous, appropriately so given the heterogeneous nature of our texts. But it is important to acknowledge as we go about our editorial work that the aims of that work are the same, grosso modo: to preserve, understand, and communicate the textual legacy of the past.

Unlike the classicist, the medievalist can say, to paraphrase Andrew Dunning, 'if I need an edition of a particular text to do my work, I just find a good manuscript and make one.'2 Classicists meanwhile are weighed down by the legacy of what was once a great strength of the field, the existence of critical editions, and usually more than one, for the majority of our texts. These editions can be still be improved upon in significant ways - Richard Tarrant gives a list of the some of them

This lecture was given at the Ars edendi concluding conference I 8 August, 2016.

${ }^{\text {I }}$ Cf. Elisabet Göransson, 'Networking the Case Studies: Editorial Methods and the Editorial Circle Model', in The Arts of Editing Medieval Greek and Latin: A Casebook, ed. by E. Göransson et al. Studies and Texts 203 (Toronto: PIMS, 20I6), pp. 400-429, p. 403 ('the link'), p. 427 ('mediation'), and esp. p. 428 ('build a bridge between the complex material and the reader by means of an edition').

2 'Where a printed version of a medieval text does not allow me to answer my research questions, my solution has been to create a new edition of a significant manuscript, giving credit to the intellect of earlier editors by citing their corrections.' Quotation from his blog post of 7 May 2015, 'Networking Scholarly Editions,' https:// medium.com/@dunning/networking-scholarly-editions-ec38fdefefof (accessed I7 April 2020).

How to cite this book chapter:

Damon, C. 2020. On editing the reception of Pliny's Natural History. In: Kihlman, E. and Searby, D. (eds.). Ars Edendi Lecture Series. vol. V. Pp. 29-66. Stockholm: Stockholm University Press. DOI: https://doi.org/Io.I6993/bbd.d. License: CC-BY 
in 'The future: Problems and prospects,' the final chapter of his recent book on Latin textual criticism ${ }^{3}-$ but the bigger challenge confronting us at the moment is to get those critical editions into digital form so that they can join the various modern scholarly conversations about texts and literature. And that brings us back to the pathways that enable such conversations. In the present paper I proceed along some still quite rickety pathways in the hope that eventually a proper infrastructure will be built.

During the past ten years or so I have been on a steep learning curve. As a graduate student I decided not to follow my dissertation supervisor, Ted Courtney, into the area of textual criticism. He had made a distinguished career as an editor of classical texts, but at that time - the I980s - the job market for classicists did not look with favor on that sort of work. ${ }^{4}$ As the years passed, however, and I became increasingly aware of the new digital ecosystem into which classical texts were being migrated, I realized that my pragmatic graduate-student decision had left me woefully underequipped to contribute productively to this movement. So, I decided to learn something about textual criticism, and to look for allies in the quest for better texts.

Phase one of this assignment took a very traditional form: I did an old-fashioned edition for the old-fashioned Oxford Classical Texts series. It could hardly have been more retro: the text was a military narrative by Julius Caesar, and the type of edition that this tradition called for was classically Lachmannian, stemma and all. It was good for the elementary education I needed, but the further I got into the project the more I could see of the broader editorial landscape.

Phase two of the assignment accounts for a much steeper part of the aforementioned learning curve. This is the part concerned with finding allies who are themselves eager to obtain and if necessary, produce good digital editions of works with transmission histories comparable to those of the classical texts I study. As a practical matter I

3 R. J. Tarrant, Texts, editors, and readers: Methods and problems in Latin textual criticism (Cambridge: Cambridge University Press, 2016), p. I45.

4 Twenty years later the picture remained much the same, see D. Shanzer, 'Editions and editing in the classroom: A report from the mines in America,' in Vom Nutzen des Edierens: Akten des internationalen Kongresses zum I 50 -jährigen Bestehen des Instituts für Österreichische Geschichtsforschung, Wien, 3.-5. Juni 2004, ed. by B. Merta et al. (Wien: Oldenbourg, 2005), pp. 355-368. It would be nice to think that the push for digital editions will revive the appreciation of editorial work in the field of Classics. For some hopeful signs see http://digitallatin.org/ (accessed I 7 April 2020). 
am concentrating on texts written in Latin, but that limitation is not inherent to the project itself. The text I have chosen as a focus for this phase is Pliny's Natural History, which seems to me both interesting in itself and, in view of its robust reception history, a promising source of alliances. The Natural History is also a text that challenges familiar ideas about what a text is, and such challenges have always been a stimulus to editorial innovation. Plus, in following the traces of Pliny's Natural History through the centuries I came upon an admirable recent edition of another text with a large debt to Pliny, so I decided to use that edition to explore the question of how best to reveal the echoes of and transformations to Pliny's text.

More precisely, I will look at what happens to the ninth book of Pliny's Natural History, the fish book, in the Speculum naturale of Vincent of Beauvais, where fish are the topic of the seventeenth book. This will illustrate, I hope, the value of networked and dynamic information for the study of reception and sources, since it addresses the challenge of coping editorially with the presence of texts within texts, the topic of a number of stimulating papers in the Ars edendi Casebook.5 Pliny's Natural History is of course a prime example of a text that is built of material taken from earlier texts, but relatively few of his sources survive intact. The Natural History, by contrast, and despite a complicated transmission history, is basically here with us today, standing ready to shake hands across the centuries with texts that reproduce and repurpose its words. The question before us is, how can we make the contact between texts as informative as possible? What sorts of pathways do we need?

5 The Arts of Editing Medieval Greek and Latin: A Casebook, ed. by E. Göransson et al. Studies and Texts 203 (Toronto: PIMS, 20I6). The challenge is of course relevant well beyond the encyclopedic sphere, and a variety of approaches to satisfying it have already been devised. See, for example, for an encyclopedic text Ilse De Vos et al., eds, 'L'art de compiler à Byzance: La lettre $\Gamma$ du Florilège Coislin', Byzantion 78 (2008): I 59-223, and eadem, 'La lettre B du Florilège Coislin: editio princeps', Byzantion 80 (2010): 72-I20); for an epistolary text, Jeffreys, Elizabeth, and Michael Jeffreys, eds, Iacobi Monachi Epistulae. Corpus Christianorum Series Graeca 68 (Turnhout: Brepols, 2009) with discussion by Elizabeth Jeffreys in 'Tapestries of quotation: The challenges of editing Byzantine texts', in Ars Edendi Lecture Series, Volume II, ed. by A. Bucossi and E. Kihlman. Acta Universitatis Stockholmiensis: Studia Latina Stockholmiensia LVIII (Stockholm: Stockholm University, 20I2), pp. 35-6I, and by Macé, C, 'Rules and guidelines in book series and their impact on scholarly editions', in E. Göransson et al., pp. 248-266. Other papers in The Arts of Editing that deal with the editorial challenge of embedded texts include those by Andrée, Bucossi, Crostini, and Hicks. 


\section{Hortus sanitatis ... Speculum naturale ... Naturalis historia}

The work that will furnish my point of departure is the 2013 edition of De piscibus by Catherine Jacquemard and a team based at Caen. ${ }^{6}$ The Depiscibus is the fourth book of an 8-book compendium called the Hortus sanitatis printed in Mainz in I49I. The Hortus was originally given to the world without an author's name, and its modern editors describe it as a last belated flowering of the encyclopedic urge that peaked some two centuries earlier.7 In book form the edition is impressively learned and aesthetically pleasing. The Latin text is supported by notes on the text, notes on the content, and a facing-page French translation. The layout is clear and spacious, and the editors incorporate the woodcut illustrations that appeared on almost every page of the Hortus into the presentation and analysis. There is also a long and helpful introduction. I have found only one brief published review, but I will stick out my non-medievalist neck and say with that reviewer that it is an admirable edition: 'claire, complète, et prudente, un modèle du genre.' The print volume is only the half of it, for the material is also published online in a version that offers additional functionalities, including one that was very helpful for me in trying to track down Plinian material in the Hortus. ${ }^{9}$

The Hortus is basically a compilation of texts that were themselves compilations. For the fish of Book 4, the most important source was a compendium produced in the mid-thirteenth century, the Speculum naturale of Vincent of Beauvais. Both points are made with exemplary clarity in the 2013 edition. In the print edition of the chapter on snails, cochleae, for example, the Latin text and a woodcut illustration occupy the right-hand side of page I97, the references to Vincent and Pliny the

${ }^{6}$ Jacquemard, C. et al., eds, L'Hortus sanitatis, Livre IV: Les poissons (Caen: Presses Universitaires de Caen, 2013).

7 Jacquemard, L'Hortus sanitatis, pp. 46-47.

${ }^{8}$ Van den Abeele, B., Review of Jacquemard, C. et al., eds, L'Hortus sanitatis, Livre IV: Les poissons (Caen: Presses Universitaires de Caen, 20I3), Scriptorium 69 (2015), I 82-I 83 .

9 https://www.unicaen.fr/puc/sources/depiscibus/accueil (accessed I 7 April 2020). The planning and work that went into the website are well documented: Jacquemard, C., and P.-Y. Buard, 'Le projet Ichtya entre édition critique et constitution de corpus', Schedae, prépublication I4, fascicule I (20II), I39-I52, Gauvin, B., et al., 'Emprunts, compilation, et réécriture dans l'Hortus sanitatis,' Schedae prépublication I (20II), I-2I; Jacquemard et al., 'L'Hortus sanitatis: Transmission et réorganisation de la matière encyclopédique au XVe siècle', Revue d'histoire des textes, n.s. VII (20I2): 353-369; and P.-Y. Buard, Modélisation des sources anciennes et édition numérique (PhD diss. Université Caen, Normandie, 2015). 
left, and the text of Pliny excerpted by Vincent the footnotes. The online version of the page is a little different: the references to Vincent and Pliny are now hidden behind the siglum [.] and only appear if you hover over it. ${ }^{\text {I0 }}$ This version of the page looks less like a critical edition and more like the original Hortus, which copies but does not cite Vincent and cites but does not reproduce Pliny. ${ }^{\text {II }}$ The fish book of the Hortus sanitatis comprises 106 chapters about specific fish arranged in rough alphabetical order. To make a very long story very short, the compiler of the Hortus imported Vincent's chapters on specific fish wholesale. The Hortus gives the reader information about the source of each datum, but cuts out the middleman, so to speak. One of the many virtues of the 2013 edition of the De piscibus is to put Vincent back into the picture after 500 years of erasure.

Now as many a frustrated medievalist knows, it is not easy to work on Vincent of Beauvais. ${ }^{\mathrm{I2}}$ The edition that is still the standard for citation today was published in I 624. I will discuss its methodology briefly below, but for the moment it is enough to say that it lacks some crucial features of a modern critical edition, even if it is available online in searchable form. ${ }^{13}$ The 2013 De piscibus edition, as I said, puts Vincent back into the picture by providing references to the Speculum naturale. The edition was designed to interact with the digital version of the I624 Speculum prepared by the Atelier de Vincent de Beauvais. ${ }^{\mathrm{I}}{ }^{4}$ This

to https://www.unicaen.fr/puc/sources/depiscibus/consult/hortus_fr/FR.hs.4.23 (accessed I7 April 2020).

ir The online version of De piscibus also contains page images from two fifteenthcentury editions of the Hortus, including this page on the cochleae, citing 'Pli.li.ix': https://www.unicaen.fr/puc/sources/depiscibus/ui/images/Template.php ?edition=Prussi \&vue=I 2 (accessed 28 July 20I 7 ).

${ }^{12}$ For a recent overview of the difficulties see M. Franklin-Brown, Reading the World: Encyclopedic Writing in the Scholastic Age (Chicago: Chicago University Press, 20I2), pp. xvi-xxii.

I3 Website: http://sourcencyme.irht.cnrs.fr/encyclopedie/voir/I33 (accessed I7 April 2020). One can also find manuscripts of the Speculum online, including this one from the fifteenth-century: http://daten.digitale-sammlungen.de/ db/o००3 /bsbo003 5779/images/index.html?fip= I93.I 74.98.30\&seite $=5$ \&pdfseitex $=$ (accessed I7 April 2020).

${ }^{14}$ Jacquemard et al., 'Transmission et réorganisation', p. 353. Here is how the texts on the Sourcencyme site, the Speculum naturale among them, are described: 'Les textes ont été enregistrés suivant les éditions ou les manuscrits indiqués. Il s'agit donc de transcriptions, pas de nouvelles éditions du texts. Cependent, des corrections (signalées) ont été apportées, par exemple pour corriger de coquilles, rétablir la graphie médiévale en supprimant les diphtongues appliquées par les éditeurs de l'époque moderne, proposer une meilleure leçon en cas de leçon incompréhensible, etc. Ces aménagements ne disposent donc pas de retourner à l'édition critique ou, 
is a very useful text, and especially so in Vincent's book about fish, Book I7, since the De piscibus team supplied precise references for Vincent's Pliny extracts. That is as far as the interaction between these two projects has gone to date, so in practice one has to use the two sites in tandem. But this particular pathway is well begun.

Back to tracking down Plinian material in the Hortus. With a little persistence one can assemble a chain of texts pertaining to each of about roo fish. For each fish, the Hortus contains a copy, sometimes truncated and occasionally garbled, of the Speculum chapter or chapters on said fish, and many of the Speculum chapters contain extracts of one or more Pliny passages. Here is the 'chain' for snails, with the Hortus at the top, Vincent in the middle, and Pliny at the bottom.

Hortus sanitatis 4.23.I: Cochleae aquatiles terrestresque sunt exerentes se domicilio, binaque ceu cornua protendentes contrahentesque. Oculis carent, ideoque corniculis earum praetentant iter.

Speculum naturale I7.45.I: Cochleae aquatiles terrestresque sunt exerentes se domicilio, binaque ceu cornua protendentes contrahentesque, oculis carent. Ideoque corniculis earum pretentant iter.

Naturalis historia 9.IоI: In eodem genere cocleae aquatiles terrestresque, exerentes se domicilio binaque ceu cornua protendentes contrahentesque, oculis carent; itaque corniculis praetemptant iter.

In the description of the Hortus given above I have simplified the situation slightly, because some of its chapters are based on Albert the Great, not Vincent, and both medieval compendia cite more sources than Pliny, and some of the sources they cite, such as Isidore, also cite Pliny, and so on, but the basic picture of a chain of sources is sound. The details underlying the expression 'extracts of one or more Plinian passages' will occupy us in the fourth and fifth sections of this paper.

\section{Compiling extracts}

Before I get to the philological details, however, here are some numbers to provide a broad sense of the relationship between the texts of the thirteenth-century Dominican friar Vincent and the first-century Roman administrator Pliny. The first numbers come from a chart published by Baudouin Van den Abeele in I997 as an appendix to his paper on the

le cas échéant, à l'édition ancienne ou manuscrit.' (http://sourcencyme.irht.cnrs.fr /encyclopedie/liste [accessed I7 April 2020]). 


$\begin{array}{llllllll}\text { IIo } & 33 & \text { XIo } & \text { I23 } & \text { XXo } & 77 & \text { XXIXo } & 58 \\ \text { IIIo } & 0 & \text { XIIo } & 44 & \text { XXIo } & 37 & \text { XXXo } & 38 \\ \text { IVo } & 0 & \text { XIIIo } & 32 & \text { XXIIo } & 44 & \text { XXXIo } & \text { I I } \\ \text { Vo } & 6 & \text { XIVo } & 24 & \text { XXIIIo } & 34 & \text { XXXIIo } & 40 \\ \text { VIo } & \circ & \text { XVo } & 46 & \text { XXIVo } & 55 & \text { XXXIIIo } & \text { I } 5 \\ \text { VIIo } & 8 & \text { XVIo } & 9 \mathrm{I} & \text { XXVo } & 44 & \text { XXXIVo } & \text { I } 4 \\ \text { VIIIo } & \text { I } 6 & \text { XVIIo } & 57 & \text { XXVIo } & \text { I9 } & \text { XXXVo } & 9 \\ \text { IXo } & 72 & \text { XVIIIo } & 58 & \text { XXVIIo } & \text { I9 } & \text { XXXVIo } & 4 \\ \text { Xo } & \text { I } 4 & \text { XIXo } & 44 & \text { XXVIIIo } & 54 & \text { XXXVIIo } & 2\end{array}$

Figure 1. Citations of $\mathrm{NH}$ books $2-37$ in the Speculum naturale, using the formula "Plinius libro ...."

sources of the animal lore in the Speculum naturale. ${ }^{15}$ His chart shows the number of extracts per source in $S N$ 16-22, which cover the animal kingdom, or the products of the fifth and sixth days of creation, to use Vincent's narrative framework. Pliny's 979 extracts are more than twice as numerous in these books as those of the next most important source, the Liber de natura rerum by Vincent's contemporary Thomas of Cantimpré, and nearly three times as numerous as the 376 citations of Aristotle in his Latin guise. ${ }^{16}$ Other classical authors are far down the list, including poor Cicero with exactly one. A comparable chart is given in the 2013 edition of De piscibus, showing that Pliny's predominance persists two centuries on. ${ }^{17}$ Equally impressive is the coverage of Vincent's Pliny extracts, which I summarize for the Speculum naturale in Figure I.

Vincent cites the great majority of Pliny's thirty-six content books with markers of the form Plinius libro secundo etc. (Book 37 is the last book of the Natural History, and Book I contains only a preface and an index.) The only books Vincent ignores are those on geography, Books 3-6. The numbers themselves are not important - or even precise, since

I5 B. Van den Abeele, 'Vincent de Beauvais naturaliste: Les sources des livres d'animaux du Speculum naturale', in Lector et compilator: Vincent de Beauvais, frère prêcheur: Un intellectuel et son milieu aux XIII ${ }^{\mathrm{e}}$ siècle, ed. by M. Paulmier-Foucart and S. Lusignan (Grâne: Créaphis, I997), pp. I 27-I 5I, pp. I44-I45.

${ }^{16}$ And the real extent of Vincent's debt to Pliny is somewhat larger still, since the works of Thomas and the next most prominent source, Isidore, themselves contain a lot of Plinian material.

${ }^{17}$ Jacquemard et al., L'Hortus sanitatis, from 'Annexe 2: Sources des citations réferencées dan le Tractatus de piscibus, répartation quantitative par auteur': Pline l'Ancien 86, Thomas de Cantimpré 84, Aristote 26. 


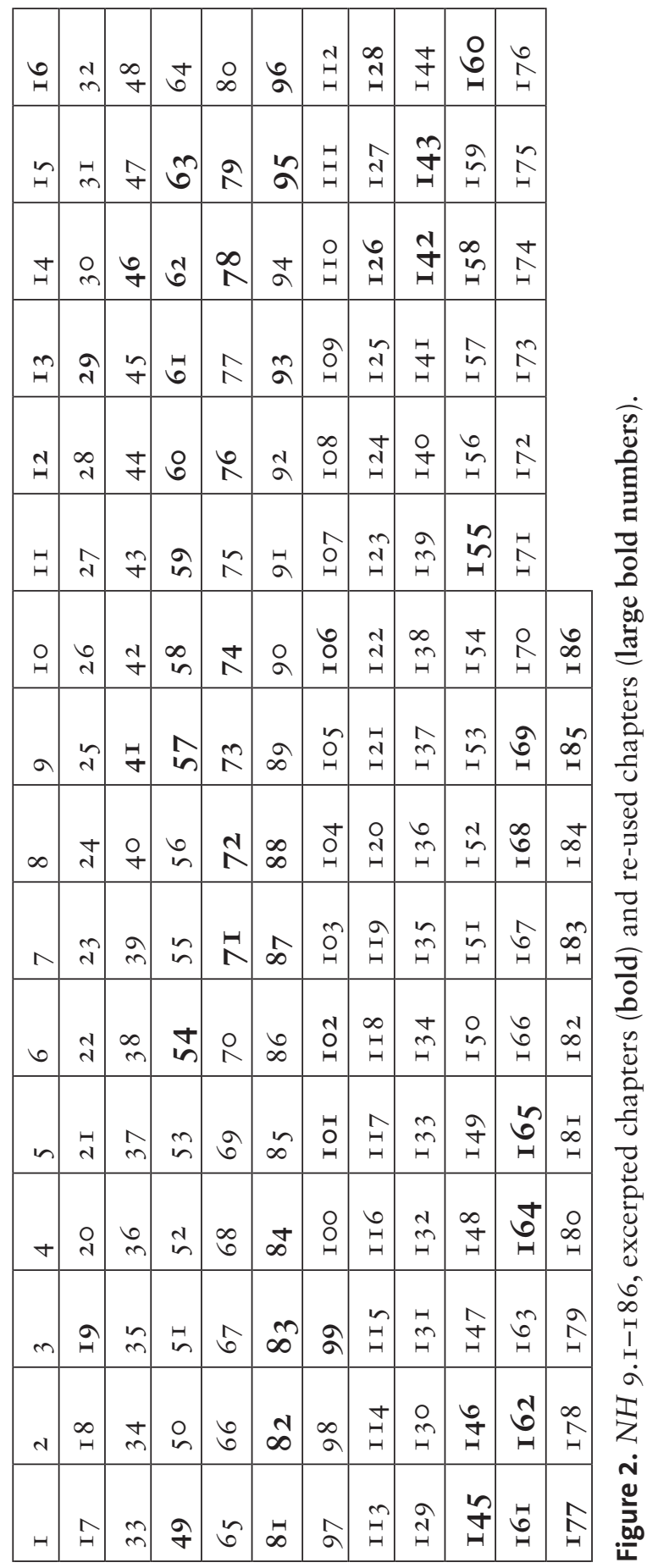


the actual count is much higher owing to citations introduced by Plinius eodem or Plinius ubi supra, etc.- but even this glimpse shows that the major fish books, 9 and 32, are well represented in Vincent's Speculum, with 72 and 40 direct references respectively; $\mathrm{NH} 9$ treats fish themselves, $\mathrm{NH}_{32}$ discusses remedies derived from fish and other creatures.

The next number-based figure shows the volume and rough distribution of Vincent's extracts from Pliny's fish book. Each cell in Figure 2 represents a chapter of $\mathrm{NH}$, and the bold-numbered cells represent those that were excerpted in Vincent's fish book, Book 17.

The distribution is somewhat uneven, the more so if one takes into consideration the fact that some chapters - those with larger numbers in bold font - are cited more than once; there is also a noticeable gap about two thirds of the way through the book (Ch. I07-I26) to which we will return. Still, it is clear that Vincent's extracts are drawn from a wide range of paragraphs in $\mathrm{NH}$ 9. In short, Pliny was a major source for Vincent, and the pathway from one encyclopedist to the other seems worth investigating.

\section{From text to text}

This is easier said than done. I alluded above to the difficulty of working on Vincent's massive Mirror, which runs to more than three million words in length and appeared in at least three different versions in the middle of the thirteenth century. Earlier scholars perforce limited themselves to broad-brush characterizations of Vincent's extracts, such as 'citations livrées telles quelles' or 'textes ... reproduits dans les mots mêmes de l'auteur.' ${ }^{\text {I8 }}$ Such an understanding of the excerption process underpins the online edition that I mentioned above, which at best gives a bare reference to Pliny by book and chapter, and more often than not by book alone. The 'dans les mots mêmes' view also justifies (sort of) the editorial practice of the 1624 edition, which proudly claims on its title page to have vetted Vincent's extracts against their originals and corrected the text where the two did not match, 'the exact wording of each author's statements having been restored' (suis unicuique autori

I8 Van den Abeele, 'Vincent de Beauvais naturaliste', p. I35, and M. Paulmier-Foucart and M.-C. Duchenne, Vincent de Beauvais et le Grand Miroir de monde (Turnhout: Brepols, 2004), p. 35: 'la plupart des textes retenus sont reproduits dans les mots mêmes de l'auteur; il ne s'agit pas de résumer, sauf exception pour des textes narratifs, en particulier hagiographiques, et pour les extraits d'Aristote, mais il s'agit bien de faire des extraits, en abrégeant éventuellement selon les règles grammaticales courantes ....' 
redditis exacte sententiis). ${ }^{19}$ But in doing justice to Vincent's sources the editors have overruled Vincent's own editorial decisions. Recent scholars now point to the I 476 edition as being more faithful to Vincent's manuscripts. ${ }^{20}$ But leaving that can of worms aside, even Vincent's references to the excerpting process suggest that 'telles quelles' and 'dans les mots mêmes' misrepresent the relationship between our two texts.

The clearest evidence comes from the second version of Vincent's introductory liber apologeticus. ${ }^{21}$ In the apologia Vincent speaks with some exasperation, cum stomacho he says, to critics who have accused him of adulterating the excerpted texts. ${ }^{22}$ Specifically, of changing the order of the words and the words themselves. As he explains the process, 'The words have generally been rearranged, and there have been occasional slight alterations to the form of the words themselves, but the authority's opinion is still present. ${ }^{23} \mathrm{He}$ argues that this approach was dictated by the need to reduce verbiage (prolixitatis abbreviande), unite disparate passages (multitudinis in unum colligende), and clarify obscurity (obscuritatis explanande). His policy, he says, like Jerome's, was not verbum e verbo but ex sensu sensus, and he is deterred from it

${ }_{19}$ The editor, Balthazar Bellerus, in introducing the book to readers (specifically, to the Benedictine Collegium Vedastinum in Douai), speaks of a citationum fidelis recensio, saying that he and the printer collated the Speculum text against manuscripts and two printed editions, and that they collated and emended the extracts themselves. How far their diligence - the title-page motto is labore et perseverantia - extended has yet to be determined. See also Franklin-Brown, pp. xx-xxii and C. Silvi, 'Citer Pline dans les encyclopédies médiévales: L'exemple des notices zoologiques chez Thomas de Cantimpré et Vincent de Beauvais', Archives internationales d'histoire des sciences, 6I (20II), 27-55, p. 39 n. 50.

${ }^{20}$ For a link to an online copy see note I 3 above. SN I 7 starts on $347 \mathrm{v}$ for the index, $348 \mathrm{v}$ for the text.

${ }_{21}^{21}$ This brief but important apologia is the only bit of the Speculum to have appeared in a modern edition, that of Serge Lusignan, Préface au Speculum maius de Vincent de Beauvais: Réfraction et diffraction (Montreal: Bellarmin, I979), which presents its first and second versions.

22 The chapter, entitled 'Apologia de modo excerpendi in quibusdam libris Aristotilis,' focuses on the extracts from Aristotle made by his assistants (quos nequaquam ego ipse excerpseram, sed a quibusdam fratribus excerpta susceperam). But that the method was applied more widely is suggested towards the end of the chapter, where he defines the relevant material thus: de flosculis Aristotilis et de ceteris quos in hoc opere per diversa capitula inserui et propriis actorum nominibus annotavi. On Vincent's use of assistants see also lib. apol. 3, which appears in all versions of the liber: non omnia manu propria, sed pleraque per manus notariorum abbreviavi, ut potui. For the liber apologeticus and its various versions see Lusignan, Préface; the text quoted here is taken thence.

${ }_{23}$ Lib. apol.1o ordine plerumque transposito, nonnunquam mutata paululum ipsorum verborum forma, manente tamen actoris sententia. 
neither by pricks of conscience nor by attacks from contemporaries. In fact, he retorts that those who don't approve of his policy should check his extracts against the originals before complaining about them. ${ }^{24}$ 'I'd ask them to read the passages first, and compare them with the originals, and then turn up their noses, if they please.' That is what I propose to do in the balance of this paper, not in order to turn up my nose, but with an eye to how editors might make it easier for scholars to take up Vincent's challenge, 'Legant, obsecro.'

One last bit of overview, this one designed to convey the scope of the differences that you will find if you read Vincent's extracts against Pliny's original. ${ }^{25}$ The details are given in Appendix I, which contains the direct extracts from Pliny's Book 9 in Vincent's Speculum that were carried over into the Hortus. Graphic variations in the Appendix indicate how much of Vincent's extract differs from Pliny's original and roughly how it differs, with different indicators for ( $I$ ) variations in word order, (2) additions, usually of connectives and explanatory particles, (3) simplifications to vocabulary or lists, (4) clarifications, (5) alterations of meaning, and (6) readings in Vincent and the Hortus that appear in the apparatus but not the text of modern Pliny editions. How many of the eighty-four extracts transmit Pliny's original 'dans les

${ }^{24}$ Lib. apol. Io Legant obsecro prius et cum originalibus suis conferant, ac postmodum si videtur eis despiciant. Some intrepid scholars have recently done just that, including Christine Silvi, who concludes, apropos of Pliny, that 'l'HN n'est pas seulement abrégée, réorganisée, remise en ordre, en un mot réécrite pour être adaptée aux contraintes de la notice, elle est aussi dénaturée, corrompue, d'où des approximations dan les citations, des reformulations parfois maladroites, des fautes aussi' (Silvi, pp. 43-44). Similarly on page 37: 'Citer Pline, ce n'est pas recopier ce que Pline a écrit, c'est d'abord localiser et sélectionner, abréger, synthétiser, dénaturer et corrompre aussi, quand ce n'est pas mettre à distance et finalement dominer l'énorme masse d'informations contenues dans l'HN dans le but de les adapter aux contraintes de la notice, élément de base de l'encyclopédie médiévale.'

25 The broad scope of Vincent's changes also comes across in the summary of Eva Albrecht's 2007 dissertation, De ontstaansgeschiedenis en de compilatie van het Speculum Naturale van Vincent van Beauvais ( + 1264), published in the online Vincent de Beauvais Newsletter: 'Vincent a élaboré ses sources d'une manière tres intensive. Il ne s'est pas limité à simplement copier les citations. Alors qu'il citait régulièrement ses sources d'une manière textuelle, il n'a pas hésité à sauter des passages, à adapter le début et la fin d'un passage au contexte du chapitre concerné, ou à inverser l'order de la source. Si nécessaire il a résumé les sources ou les a paraphrasées. Aux passages un peu obscurs, il a ajouté ses propres explications didactiques. Une fois prêts, les traités pouvaient ensuite être copiés et reliés dans les manuscrits.' (http://www.vincentiusbelvacensis.eu/bibl/recent.html; accessed I 7 April 2020). 
mots mêmes'? Only four. ${ }^{26}$ Now let us take a closer look at these differences and how students of Pliny's reception might communicate them.

\section{Legant, obsecro}

It might seem that a citation of the Plinian original would suffice to reveal the divergence between Pliny and Vincent. But things are rarely so simple. Apropos of the echeneis, or remora, for example, Vincent tells us that it is used as an amulet to prevent miscarriages and is therefore preserved in salt (presumably to reduce the nastiness of having a dead fish tied to one's body for months at a time).

SN I7.5 I.2 = HS 4.36.10 Plinius libro XXIIo: Echineis vel echinus gravidis adalligatus usque ad maturitatem continet lubricos partus ideoque asservatur sale.

Pliny in Book 22: The echeneis or echinus, when worn by pregnant women as an amulet, keeps fetuses in up to maturity-they are inclined to slip out-and is therefore preserved in salt.

What Pliny says, as the citation supplied by the editors of De piscibus tells us, is that the marvel of miscarriage-prevention is an idea purveyed by 'some Greeks,' and that he credits the fish-preserved-in-salt idea to some other sources, who maintain that it induces labor. ${ }^{27}$

NH 32.6 mirumque, e Graecis alii lubricos partus atque procidentes continere ad maturitatem adalligatum, ut diximus, prodiderunt, alii sale adseruatum adalligatumque grauidis partus soluere, ob id alio nomine odinolyten appellari.

${ }^{26}$ The relatively short bits that are adopted without change are: $H S$ 4.26.3 $=S N$ I7.II4.3 = NH 9.82 Draco marinus captus et immissus in arenam cavernam sibi

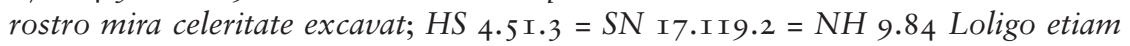
volitat, extra aquam se efferens; HS 4.67.7 = SN I7.78.6 = NH 9.160 Pectines sponte naturae arenosis proveniunt; HS 4.92.3 = SN 17.96.2-3 = NH 9.143 Novit torpedo vim suam, ipsa non torpens mersaque in limo se occultat. The information in Appendix I pertains to extracts that appear in the alphabetic list of fishes in De piscibus. The amount of alteration here is perhaps higher than in the longer extracts in the earlier part of Vincent's Book I7, but I have not compared the texts there systematically (see further notes 37,42 , and 47 below).

27 The De piscibus editors also supply notes that explicate the confusion between the echeneis and the echinus, or sea urchin (e.g., 236 n. I, and 239 n. d', and the relevant entry in the 'Catalogue des créatures aquatiques décrites dans le Tractatus de piscibus' (102). Like them, I cite Pliny from the Budé editions of de Saint-Denis (1955, I966). 
An amazing thing that, as I said, some Greeks reported, is that, worn as an amulet, it keeps fetuses in up to maturity when they are inclined to slip out and actually emerging. Other Greeks reported that, preserved in salt and worn by pregnant women as an amulet, it releases fetuses and for this reason is called by another name 'releaser of birth-pangs'.

Comparing the Speculum text and the Plinian original, as Vincent asks us to do, we learn that the book number he cited is wrong (32, not $\left.22^{28}\right)$, and that he has excised Pliny's Greeks and his amazement at the works of nature, expressed, as often, by the term mirum. We also see that Vincent has omitted the labor-inducing function of this fish amulet. Why? Is it uninteresting or otherwise objectionable, and if so, why? ${ }^{29}$ Or perhaps we should instead take this excision as a testament to the power of etymology, since the extract from Isidore that opens the discussion of the fish in question asserts that the echeneis was so called 'from the fact that it holds a ship back by attaching itself' ( $S N$ I 7.49.I: ex eo quod navem adhaerendo retineat). ${ }^{30}$ It makes sense that a ship-delaying fish should delay fetuses, too, but it may have seemed counterintuitive that it should induce labor. ${ }^{3 \mathrm{I}}$ Another possibility, however, is that Vincent echoes the language of this Pliny passage from Book 32 here (ad maturitatem and lubricos partus are particularly close) but reproduces the content of a passage to which Pliny gives a back-reference in $u t$ diximus. For in his Book 9 discussion of the remora Pliny reported miscarriage prevention but not labor induction:

NH 9.79 est paruus admodum piscis adsuetus petris, echeneis appellatus ... fluxus grauidarum utero sistens partusque continens ad puerperium.

There is a fish, quite small and adapted for rocky areas, called echeneis ... stopping the vaginal fluxes of pregnant women and keeping fetuses in until delivery.

Vincent cited the sentence that follows this one earlier in his discussion of the echeneis ( $S N_{17.49 .4}=H S_{4.36 .3} \approx N H$ 9.79), so in I7.5 I.2 he

${ }_{28}$ On errors in Vincent's book numbers see Silvi, p. 39 n. 5 I.

${ }^{29}$ It may (or may not) be relevant that Vincent had earlier reported that snails, taken as food, induce labor ( $S N$ I7.45.2).

${ }^{30} \mathrm{HS}$ 4.36.I = SN I 7.49. I Isidorus: Echeneis parvus et semipedalis pisciculus, nomen sumpsit ex eo quod navem adherendo retineat. Ruant licet venti, seviant procelle. Navis tamen radicata in mari stare videtur nec moveri, non retinendo, sed tantummodo adherendo: hunc Latini remoram appellaverunt, eo quod cogat stare navigia ipsa.

${ }^{31}$ For a discussion of an entry in the Speculum that embraces conflicting information see Franklin-Brown, pp. 223-232 on the rana. 
may have blended two disparate bits of Pliny. In other words, the juxtaposition of two passages facilitated by the De piscibus edition answers some questions about the relationship between Vincent and Pliny, but raises others that require access to more of the source text, and possibly also to more of the target text if one is curious about Vincent's attitude to Greeks, or the marvels of nature, or abortifacients.

The point is even clearer in a passage from Vincent's chapter on the squatina, or angel-shark.

SN I7.94.3 = HS 4.84.3 Plinius libro XIo: Squatina est ex piscium genere qui pro spina cartilaginem habent.

Pliny in Book Ir: The angel-shark belongs to the category of fish that have cartilage instead of a spine.

Vincent credits Pliny's Book I I with this information, but the citation supplied by the editors of the De piscibus is from Pliny's Book 9.

NH 9.78 Planorum piscium alterum est genus quod pro spina cartilaginem habet, ut raiae, pastinacae, squatinae [...]

There is another category of flat fish that has cartilage instead of a spine, for example rays, prickly rays, angel-sharks, ...

The verbal alignment is close enough to make the identification of Vincent's source plausible, and the difference in number suggests that there is again an error in Vincent's marker. ${ }^{32}$ But the Pliny citation has more to tell us: we can see that Vincent has trimmed away references to similar fish at both the front and rear ends of his extract. Pliny's alterum links this passage about 'another category of flat fish' to a previous discussion of flat fish, at $\mathrm{NH} \mathrm{9.72.} \mathrm{And} \mathrm{the} \mathrm{citation} \mathrm{ends} \mathrm{with} \mathrm{a} \mathrm{list} \mathrm{of}$ squatina-like fish, which continues into the editors' ellipsis. ${ }^{33}$ In fact, if we had the full Plinian context of the citation supplied for Vincent's extract we would see that he has elided six species, ${ }^{34}$ a reference to

${ }^{32}$ It might be also useful to have easy access to NH I I, if only to assure oneself that there is nothing relevant there; the book is in fact about insects.

33 For another example, illustrating Vincent's extraction of the mouse from a Plinian list of animals that are neither wild nor tame, see Silvi, pp. 42-43 on SN I9.126, adapting $\mathrm{NH} 8.22-2 \mathrm{I}$.

34 A fuller version of the Pliny passage is given earlier in $S N$ I7.I9 on de diversis figuris piscium, which is part of the general discussion of marine creatures that precedes Vincent's alphabetic list of specific fish. Here too the reference to Aristotle and Pliny's coinage are missing, as they are in a third related passage, SN I7.I09.3 on the dolphin. 
a terminological innovation by Aristotle, and a Latin coinage offered rather coyly by Pliny, who seems unwilling to be outdone by the Greek naturalist.

NH 9.78 Planorum piscium alterum est genus, quod pro spina cartilaginem habet, ut raiae, pastinacae, squatinae, torpedo et quos bouis, lamiae, aquilae, ranae nominibus Graeci appellant. quo in numero sunt squali quoque, quamuis non plani. haec Graece in uniuersum selaches appellauit Aristoteles primus hoc nomine iis inposito. nos distinguere non possumus, nisi si cartilaginea appellare libeat.

There is another category of flat fish that has cartilage instead of a spine, for example rays, prickly rays, angel-sharks, the electric ray, and those that the Greeks call 'the ox,' 'the witch,' 'the eagle,' and 'the frog.' Sharks, too, are in this group, although they are not flat. In Greek Aristotle was the first to call these fish as a group the selachians, having imposed this term on them. We are unable to distinguish them-unless we want to call them cartilagineans.

That is, both the word alterum and the ellipsis symbol in the citation are tantalizing markers of a text that lives elsewhere.

The ghost of an absent presence also hangs over a textual divergence in the next sentence of the Speculum, which supplies a generalization about these cartilagenous fish.

$S_{\text {I }}$ 7.94.3 $=H S_{4.84 .3}$ Omniaque talia carnosiora sunt, et supina vescuntur.

And all fish like this are rather fleshy, and they lie on their backs to feed.

NH 9.78 Omnia autem carniuora sunt talia et supina uescuntur.

All of them are carnivorous and lie on their backs to feed.

According to Vincent, all such fish are 'rather fleshy,' carnosiora, whereas for Pliny they are 'carnivorous,' carniuora. Vincent deploys this same extract in two other passages (I7.I9.I, I7.I09.3), each time with the reading carnosiora. Where did 'rather fleshy' come from? Carnosus is a word that both he and Pliny use with some frequency, and Vincent uses it more than he uses carniuorus, but is it a deliberate substitution here, or is it the result of transmission problems? For this sentence the location of the 'text that lives elsewhere' is uncertain at present, but its lure is no less strong for that.

Answering the question of how best to effect the confrontation, and engineer the pathway, between passages of the Speculum naturale and its sources will be necessary if we want to figure out how to 'edit the 
reception' of Pliny's encyclopedia or 'edit the genesis' of Vincent's. So, my next examples are meant to suggest some further desiderata.

Here is Vincent on shellfish called conchae, including those that produce pearls:

SN I7.44.I = HS 4.22. I Plinius libro IXo: Concharum genera ${ }^{35}$ firmioris sunt teste, in quibus magna varietas apparet ludentis nature. Tot colorum differentie, tot figure, inter quas principatum tenent margarite.

Pliny in Book 9: Types of conchae are characterized by quite a firm shell, in which you can see the great variety belonging to nature at her games. So many different colors, so many shapes! Among the conchae, pearls hold first rank.

The concluding relative clause inter quas principatum tenent margarite is a bit elliptical, substituting the pearl for its fishy host, but the idea that the pearl-producing oyster holds first rank among these shellfish makes perfectly good sense. The De piscibus editors identify two Plinian passages underlying Vincent's conchae.

$\mathrm{NH}$ 9.102 Firmioris iam testae murices et concharum genera, in quibus magna ludentis naturae uarietas tot colorum differentiae, tot figurae.

Murexes and types of conchae are characterized by quite a firm shell. In these, [he exclaims] the great variety belonging to nature at her games, so many different colors, so many shapes!

NH 9.I06 Principium ergo columenque omnium rerum pretii margaritae tenent.

The first and highest rank among all precious objects is thus held by pearls.

From the gap in numbers (102, I06) it is evident that Vincent has skipped three chapters' worth of material between these two sentences. ${ }^{36}$ What is not immediately obvious is that he has reframed the value-system in which pearls hold first rank. For Pliny, as the intervening context shows, the pearl is the most costly precious object, and he devotes 20 chapters to a diatribe inveighing against their popularity and retailing

35 In the I 624 edition the text reads generis; genera is the reading of the 1476 printing of the Speculum and of the Hortus.

${ }^{36}$ Many of Vincent's 'Pliny' extracts are in fact made up of discontinuous chunks of Plinian text drawn from within a single book or from disparate books. See Silvi, p. 34 ; she mentions invisible amalgamations of up to eight distinct extracts. 
shocking stories about pearl-related extravagance ( $\mathrm{NH}$ 9.104-23).37 Vincent, however, does not find pearls of much interest, at least in the context of shellfish, where this brief extract suffices. But Pliny's pearl diatribe does find a home in the Speculum naturale: it is reassigned to the book on stones, Book 8 , where a condensed and reworked form of it occupies three longish chapters (SN 8.8I-83), the last of them entitled 'on the pearl-related extravagance of the ancients' (de luxuria antiquorum in margaritis). In the case of this extract on shellfish, then, the 'text that lives elsewhere' revealed by the citations supplied by the De piscibus editors lives both in Pliny's Natural History (9.103-IO5, the omitted chapters) and in Vincent's Speculum (8.8I-83, the chapters in the books on stones). Its absence can perhaps be ascribed, broadly speaking, to the medieval author's relocation of a heatedly rhetorical section of the ancient text. The desideratum here, I would argue, is the ability to find where a particular bit of Pliny ends up. At present one can try to find this out with a word search in the online version of the Speculum, but the search only works if you happen to hit on a word that is present in both passages, spelled the same in both passages, and rare enough that you aren't buried by an avalanche of results. The Speculum naturale and the Natural history are very long texts, after all, roughly I,200,000 words in the former, 400,000 in the latter. ${ }^{38}$

Another procedure revealed by juxtaposing Vincent and Pliny is the reuse of a single Plinian passage in multiple contexts, the cells containing large bold numbers in Figure 2 above. Pliny's NH 9.57, for example, is pressed into service five times in Vincent's Book $\mathrm{I} 7$, and Vincent has five different versions of it. The chapter is something of a grab-bag; its topics are announced in Pliny's index as 'fish that have a pebble in their heads, fish that hide during the winter, fish that are caught only on fixed

37 Pliny makes a similar point with more circumspection at $\mathrm{NH}$ 37.204: rerum autem ipsarum maximum est pretium in mari nascentium margaritis.

${ }^{38}$ The Zoomathia project, which is in partnership with the De piscibus team, is working on semantic annotation that would make such searching more efficient: $M$. Tounsi et al., 'Studying the History of Pre-modern Zoology by Extracting Linked Zoological Data from Mediaeval Texts and Reasoning on It', in The Semantic Web: ESWC 2015 Satellite Events. ESWC 2015. Lecture Notes in Computer Science, vol. 934I, ed. by F. Gandon et al. (Cham: Springer, 20I 5), pp. 406-4I 5; Tounsi, M., et al., 'Studying the History of Pre-modern Zoology with Linked Data and Vocabularies', in Proceedings of the First International Workshop Semantic Web for Scientific Heritage (SW4SH 20I5), Portorož, Slovenia, June I, 20I5. CEUR Workshop Proceedings vol. I364, ed. by A. Zucker et al. (http://ceur-ws.org /Vol-I364/), pp. 7-I4; and http://www.cepam.cnrs.fr/zoomathia/?lang=fr (accessed I7 April 2020). 
dates' (NH I.9 qui calculum in capite habeant, qui lateant hieme, qui hieme non capiantur nisi statis diebus). Here is the chapter in full:

NH 9.57 Praegelidam hiemem omnes sentiunt, sed maxime qui lapidem in capite habere existimantur, ut lupi, chromis, sciaena, phagri. cum asperae hiemes fuere, multi caeci capiuntur. itaque his mensibus iacent speluncis conditi, sicut in genere terrestrium retulimus, maxime hippurus et coracini, hieme non capti praeterquam statis diebus paucis et isdem semper, item murena et orphus, conger, percae et saxatiles omnes. terra quidem, hoc est uado maris excauato, condi per hiemes torpedinem, psettam, soleam tradunt.

A particularly cold winter is felt by all fish, but especially by those that are thought to have a stone in their heads, for example bass, the chromis, the grayling, and porgies. When the winters have been harsh, many are caught blind. Thus in these (i.e., winter) months they lie hidden in caves (as we reported concerning the class of land animals), especially the gilthead and blackfish, and are not caught except on a few fixed days, always the same days; likewise the moray eel and the orphus, the conger and perch and all rockfish. People say that the electric ray, the plaice, and the sole hide themselves in the ground-that is, in a depression hollowed out in the sea-through the winter.

The paragraph contains both general information about fish-'all fish (omnes) feel a particularly cold winter'-and lots of fish names: lupi, chromis, sciaena, phagri, hippurus, coracini, murena, orphus, conger, percae, saxatiles omnes, torpedo, psetta, solea. Vincent uses this extract in connection with three topics in his general discussion of fish at the beginning of Book $I 7^{39}$ and twice apropos of specific fish; most of the fish in Pliny's list do not get their own entries in Vincent's catalog. ${ }^{4}$ The specific fish are the lupus, or bass, and the pagrus, seabream or porgy, both of which fall into Pliny's category of 'fish that have a pebble in their heads.' Vincent's first two extracts from NH 9.57 basically split Pliny's chapter between them, but they double up on one sentence and garble the ending badly $\left(\mathrm{I}_{7.7}, \mathrm{I}_{3}\right)$. The third general extract condenses

39 The general headings under which Vincent places the extract are 'on their sense perception' (I 7.7), 'on fishes' changing from one location in the water to another' (I7.I3), and 'on fishes' variability according to the seasons of the year' (I7.I4).

$4^{\circ}$ Vincent has no chromis (but there seems to be a textual problem in Pliny here; see note below), no sciaena, no orphus. For the perca at $S N$ I 7.78.7 Vincent does not adapt Pliny but writes the text himself: Actor: Perca est piscis fluvialis varii coloris, cursu velocissimus, squamis et pinnulis acutis et asperrimis armatus, quibus etiam se defendit contra pisces maiores, ne predantes eam invadant: pre ceteris piscibus fluvialibus et stagnensibus infirmis in cibo precipue convenit. 
Pliny's chapter and gets the basic information of the ending right (I7.I4). The two extracts that are attached to specific fish truncate the passage and are similar but not identical. Apropos of the lupus Vincent says:

SN $17.65 .3=H S 4.54 .3$ Idem in libro IXo: Pregelidam hyemem omnes sentiunt pisces, sed maxime, qui lapidem in capite existimantur habere, ut lupi et pagri. ${ }^{4 \mathrm{I}}$ Cumque aspere fuerint hyemes, multi capiuntur ceci.

The same source in Book 9: A particularly cold winter is felt by all fish, but especially by those that are thought to have a stone in their heads, for example bass and porgies. And when the winters have been harsh, many are caught blind.

And apropos of the pagrus:

SN I7.78.3 = HS 4.67.3 Idem libro IXo: Omnes quidem pisces pregelidam hyemem sentiunt, sed maxime, qui lapidem ${ }^{42}$ habere in capite existimantur, ut lupi et pagri. Cumque aspere fuerint hiemes, multi ex eis ceci capiuntur, sicut de lupo iam dictum est superius.

The same source in Book 9: All fish feel a particularly cold winter, but especially those that are thought to have a stone in their heads, for example bass and porgies. And when winters have been harsh, many of these [sc. porgies] are blind when caught, as was already said above about the bass.

The word order in the second passage is different at the beginning, and it includes a back reference to the former passage at the end. As we saw earlier, Vincent tells us in the Liber apologeticus that he employed assistants in excerpting material from his sources, and some scholars attribute the sort of variations we see here to extracts by different hands, perhaps even from different manuscripts. ${ }^{43}$ But I would want to see more examples before drawing any conclusions, since the second passage here is clearly aware of the first. ${ }^{44}$ Anyway, the desideratum

${ }^{4 \mathrm{I}}$ On variations in this phrase in particular: $S N$ I7.7.4 ut lupi, coracini, sciena, pagri; I7.I4.I ut lupi, sciena et pagri; I7.65.3 ut lupi et pagri; I7.78.3 ut lupi et pagri. Coracini looks like an attempt to repair a problem in the manuscripts, which have, for chromis, various misspellings, including choromis, choramis, chorami. Coracini are mentioned later in Pliny's paragraph, beyond the end of the extract in SN I7.7.4. In $S N$ I 7.I 4. I the problematic word is simply omitted.

${ }^{42}$ The online edition of Vincent has lapide here, but the I624 edition has the correct reading, lapidem.

43 For details see notes 24-26 above, with Silvi, p. 40.

${ }_{44}$ One further example can be found in connection with the pearl extract discussed above. The sentence about the pearl's preeminence ( $S N$ I7.44.I inter quas principatum tenent margarite) appears two more times and in two other forms: at the 
suggested by this example is obviously the ability to find out where else a passage is cited.

Juxtapositions can also reveal the origin of errors. For instance, Vincent and the Hortus collapse Pliny's information about four fish that breach the ocean's surface into one. ${ }^{45}$ Is this a deliberate alteration or an unintentional slip? The Pliny passage comes in a series of fish characteristics: fish that change color (mutant colorem, 9.8I), a fish that flies (uolat, 9.82), fish that lack blood (sanguine carent, 9.83), and so on. Here is the bit about the fish that fly, along with a typical Plinian addendum about similar behaviors.

NH 9.82 Volat sane perquam similis uolucri hirundo, item miluus, subit in summa maria piscis ex argumento appellatus lucerna, linguaque ignea per os exerta tranquillis noctibus relucet. attollit e mari sequipedanea fere cornua quae $\mathrm{ab}$ iis nomen traxit.

A fish in fact flies exceedingly like a bird, the swallow-fish, likewise the kitefish. A fish that comes up to the sea's surface is called the lantern-fish for good reason, and by sticking its fiery tongue out of its mouth it sheds light on calm nights. A fish raises foot-and-a-half-long horn-like appendages out of the ocean and takes its name from them.

First Pliny mentions two 'fish that fly,' the hirundo or 'swallow' and the milvus or 'kite.' Then he mentions a fish, the lucerna or 'lantern,' that comes to the surface and sticks its phosphorescent tongue up into the air. And then he mentions a fish named for the sesquipedalian horns that it raises like periscopes; it was presumably the cornua fish he mentions at $N H$ 32.I45. But in Vincent's alphabetical compilation the kite-fish has lost its capacity of flight and acquired a phosphorescent tongue and long horns:

SN $17.66 .5=H S$ 4.55.5 Milvus subit in summa maria, piscis ex argumento appellatus lucerna: linguaque ignea per os exerta tranquillis noctibus relucet. Attollit e mari sesquipedalia fere cornua ab hisque nomen traxit.

The kite comes up to the sea's surface, a fish called 'the lantern' for good reason, and by sticking its fiery tongue out of its mouth it sheds light on calm nights. It raises foot-and-a-half long horn-like appendages out of the ocean and takes it name from them.

beginning of $8.8 \mathrm{I} .4$ (principium culmenque omnium rerum tenent margarite precia), and some way into 8.83.I (precipue ergo rerum precium tenent, ut dictum est, margarite). These earlier passages are closer to the sense of the Plinian original. The latter also contains a back-reference to the former.

45 The De piscibus edition has helpful notes on the confusion of this chapter, which involves more than the milvus. 
The excerptor chose the boundaries of his extract without regard for Pliny's verb-initial sentence structure, making 'kite' the subject of 'comes up' instead of attaching it to 'flies.' He also altered the syntax of the last clause to make 'kite' the subject of 'takes.' It is possible to grasp the logic of Vincent's alterations from the citation supplied by the editors of the Hortus-NH 9.82 above-but the point of Pliny's verb-initial sentence structure is much easier to see when the extract is read in its Plinian context, where 'a fish in fact flies' picks up on the preceding 'fish change color.' Furthermore, the comparison between the extracts and the original is unnecessarily difficult in the online version of $D e$ piscibus, since the extract of Plinian Latin, when revealed by a hovering mouse, obscures the text of the Hortus itself. There is a workaround on the page devoted to the 'Répertoire des citations,' where you can see all of the Pliny extracts next to their Hortus reworkings, but for those who want to compare the original text and its adaptation the print page is vastly superior ${ }^{46}$ However, the print page is also immutable, and in a later example we will see how that can be a problem. But for now I just highlight the desirability of being able to work outwards from a given extract.

In the next example the quoted Pliny passage does not in fact suffice to explain the Speculum extract. The passage in question appears in Vincent's chapter on the lepus, or 'sea hare,' which shares a Speculum chapter with the sea lion. It begins as follows:

SN I7.6I.I-4 = HS 4.48.I-2, 4.49.I-2 Isidorus: Leo marinus dictus est a similitudine terrestris. Ambrosius: Leo terribilis est in terris, sed dulcis in fluctibus. Lepus est animal timidum in terris, in mari formidabile, nam citam et que non facile possit auferri, corruptelam invehit. Isidorus: Lepus a similitudine leporini capitis nuncupatus est ...

Isidore: The sea lion is named from its likeness to the terrestrial lion. Ambrose: The lion is terrifying on land but gentle in the waves. The hare is a timid animal on land, a fearful one in the sea, for it brings a harmful substance that is quick-acting and not easily removed. Isidore: The hare is named from its likeness to a hare's head ...

Now comes the passage I want focus on. Here is Vincent's Pliny:

Plinius: Venena dira non cessant in lepore, qui in indico mari etiam tactu pestilens vomitum dissolutionemque stomachi protinus creat.

${ }^{46}$ The index to the Répertoire is at https://www.unicaen.fr/puc/sources/depiscibus /citations (accessed I7 April 2020). 
Pliny: Terrible poisons do not abate in the sea hare, which in the Indian Ocean causes illness by contact alone and immediately induces vomiting and a loosening of the stomach.

And here is Pliny:

NH 9.I 55 Nec uenena cessant dira, ut in lepore, qui in Indico mari etiam tactu pestilens uomitum dissolutionemque stomachi protinus creat.

Not even poisons, terrible ones, are absent, for example in the sea hare, which in the Indian Ocean causes illness by contact alone and immediately induces vomiting and a loosening of the stomach.

Only three seemingly minor alterations have been made to the wording of the Plinian original: nec has been changed to non, $u$ t has been omitted, and the word order has been simplified, replacing a nounadjective hyperbaton with a simple adjective-noun expression. These look like the sorts of changes made by an excerptor to create a standalone factoid about a named entity such as the sea hare. In Vincent's context venena dira non cessant means 'terrible poisons do not abate' in the sea hare; the dangerous character of the fish was mentioned in the citation from Ambrose, who said that the hare was a fearful animal in the sea, and Pliny apparently supplies the details: the poisons are persistent and cause vomiting and diarrhoea. But the Plinian context from which this factoid is extracted is centered on the proposition that everything that occurs on land is also found in the sea (9.1 54 admodum nibil non gignitur in mari), including annoying bugs and terrible poisons. That is, the point of Pliny's nec uenena cessant dira is that terrible poisons are no less present in the marine environment than in the terrestrial one. The sea hare is then brought on as an example of a terribly poisonous sea creature, $u$ in lepore; Pliny says nothing about the persistence or otherwise of its poisons. At a minimum, then, enough context needs to be supplied to show how the initial connective, nec, works in the original passage. Pliny's Latin is famously difficult, and little words like nec are essential sign-posts to the underlying train of thought. ${ }^{47}$ The editors of De piscibus do not supply a note about this divergence, but it would be easy enough to extend the citation in an updated version of the on-line edition.

47 Pinkster, H., 'The language of Pliny the elder', in Aspects of the language of Latin prose, ed. by T. Reinhardt et al. Proceedings of the British Academy I 29 (Oxford: Oxford University Press, 2005), pp. 239-256. 
However, in my view links to a good online version of Pliny's text would be a more effective way to supply the context for these extracts. This is hypothetical of course, since there is no good online version of the Natural History at present. But naturally I would like there to be one. And the following example, my last, shows that it needs to contain both a text and a critical apparatus..$^{8}$

Here is the beginning of Vincent's extract from Pliny on the urtica, or sea nettle, which is presumably a kind of jellyfish, juxtaposed with Pliny's version. I have underlined some significant textual divergences. (I only discuss the first divergence, but the textual analysis could be extended to the rest of the passage, which is given here for context. $)^{49}$

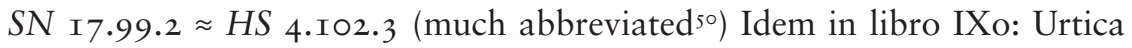
noctu vagatur noctuque mutatur. ${ }^{51}$ Carnose frontis $^{5^{2}}$ est: carne vescitur. Vis eius pruritu mordax eademque que terrestris urtice. Contrahit ergo se quam

${ }^{48}$ My example illustrates the value of having easy access to a critical edition of the Natural History. I would like to be able to show an example where it would be helpful to have a critical edition of the Speculum naturale, but as I said earlier, the standard edition was published in 1624 and its editors do not assert fidelity to Vincent's text as their highest priority.

49 The first extract in SN I7.99 concerns a different creature, the uranoscopus, and it is an imperfect digest of information from $\mathrm{NH}_{32.69}$. Here is Vincent's text: Plinius libro XXXIIo: Uranoscopus vocatur ab oculo quem habet in capite, a quo subter et supra intendit. Alio nomine gallio nuncupatur. Huius sel cicatrices sanat et carnes oculorum supervacuas consumit, ut dicit Menander in comediis. And here is Pliny's: callionymi fel cicatrices sanat et carnes oculorum superuacuas consumit. nulli hoc piscium copiosius, ut existumauit Menander quoque in comoediis. idem piscis et uranoscopos nocatur ab oculo, quem in capite habet. See the notes on HS 4.IO2.I for the garbling involved in Vincent's subter et supra and gallio.

50 The Hortus omits much of Vincent's report on the urtica, both the problematic phrase carnosae ... vescitur and everything after urticae: HS 4.I02.3 Urtica noctu vagatur noctuque mutatur. Vis eius pruritu mordax eadem quae terrestris urticae. The two cuts are related, since what follows in Vincent pertains to the foliage-like nature of the fronds of the urtica (cf. frondem, algae vice).

${ }^{51}$ In order to highlight the lemma, urtica, Vincent moves the sentence with which Pliny introduces this material to the end of his discussion: Equidem et iis inesse sensum arbitror, quae neque animalium neque fruticum, sed tertiam quandam ex utroque naturam habent, urticis dico et spongeis.

52 Frons, frontis is probably not a variant spelling for frons, frondis. Vincent repeats a grammarian's rule about forming the genitive of nouns whose nominatives end with -ns: normally you take away -s and add -tis, but frons, frondis is an exception: $S D$ 2.67. I Desinentia in $n s$, vel $r s$, vel ls, ablata s et addita tis, faciunt genitivum, ut mons, montis; ars, artis; puls, pultis; exceptis frons, frondis; lens, lendis; glans, glandis; libripens, libripendis. Forms of both frons, frontis and frons, frondis occur throughout the Speculum. 
maxime rigens ac prenatante pisciculo frontem suam spargit, complectens quem devoret. Alias marcenti similis: et iactari se passa fluctu alge vice, $\underline{\text { contractos pisces contrituque petre scalpentes pruritum invadit. Eademque }}$ noctu pectines et echinos perquirit. Cum autem admoveri sibi manum sentit, colorem mutat et contrahitur. Tacta uredinem mittit: paululumque si

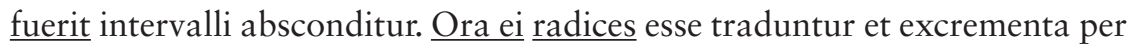
summa tenui fistula reddi.

The jellyfish moves at night and changes by night. It is a fish with a fleshy forehead, carnivorous. Its effect is an itchy sting, the same as that of a nettle on land. Accordingly, it draws itself together, becoming as stiff as possible, and when a small fish swims by it spreads its forehead, surrounding the fish it aims to devour. At other times it resembles something languid and, allowing itself to be tossed on the waves like seaweed, attacks fish that have been gathered in and are scraping away the itch by rubbing against a rock. The same fish seeks out scallops and urchins by night. When it perceives a hand approaching, it changes color and contracts. Once touched, it transmits a burning sensation and, if there a very small gap, hides itself. Their mouths are said to be 'roots' and their excrement to be emitted by a slender tube through their topmost parts.

NH 9.I 46-47 Vrticae noctu uagantur locumque mutant. Carnosae frondis hiis natura, et carne uescuntur. Vis pruritu mordax eademque quae terrestris urticae. contrahit ergo se quam maxime rigens ac praenatante pisciculo frondem suam spargit conplectensque deuorat. I47 alias marcenti similis et iactari se passa fluctu algae uice, contactos piscium attrituque petrae scalpentes pruritum inuadit. eadem noctu pectines et echinos perquirit. cum admoueri sibi manum sentit, colorem mutat et contrahitur. tacta uredinem mittit, paulumque si fuit interualli, absconditur. ora ei in radice esse traduntur, excrementa per summa tenui fistula reddi.

Jellyfish move at night and change their location. Their nature is that of fleshy foliage, and they are carnivorous. Their effect is an itchy sting, the same as that of a nettle on land. Accordingly, it draws itself together, becoming as stiff as possible, and when a small fish swims by it spreads its 'foliage,' surrounding it, and devours it. (I47) At other times it resembles something languid and, allowing itself to be tossed on the waves like seaweed, it attacks fish that have come into contact with it as they scrape away the itch by rubbing against a rock. The same fish seeks out scallops and urchins by night. When it perceives a hand approaching, it changes color and contracts. Once touched, it transmits a burning sensation and, if there is a small gap, it hides itself. Its mouth is said to be in a 'root' and its excrement to be emitted by a slender tube through its topmost parts. 
If one approaches the opening sentence of Vincent's extract with a modern text of Pliny in hand, it looks like the medieval author has prettied up a plain Plinian expression. In addition to switching the plural to the generalizing singular, an unremarkable change, he has replaced locumque mutant, 'they change their location,' with noctuque mutatur, 'it changes by night' or more literally 'is changed by night'; the anaphora is nice, but the change of voice makes the meaning objectionably vague. But before floating any theories about stylistic priorities one would be wise to check a critical apparatus for Pliny's text. Here are the notes for the lemmata locumque and mutant from the Budé and Teubner editions: ${ }^{53}$

Budé locumque Cornelissen, Mayhoff ex Aristotele: noctuque codices Teubner locumque ego ex Aristotele ( $\mu \varepsilon \tau \alpha \chi \omega \rho о \tilde{\sigma} \sigma \mathrm{l})$ : noctuque libri, veteres editores

Teubner mutantur veteres editores ante Harduinum

In the surviving manuscripts of the Natural History the opening sentence of this extract in fact reads 'jellyfish move by night, by night they change' (noctuque mutant). Vincent has repaired Pliny's lacunose syntax-mutant wants a direct object-using an equally vague but syntactically complete passive. That is, the anaphora was in the text he inherited. The emendation we read in modern editions, locumque mutant, is based on Aristotle's Greek; before Harduin's I 685 edition editors changed the voice of the verb, as Vincent did. To make a long story short, citing the text of Pliny will lead you astray ... unless of course it leads you to a critical edition of Pliny. The editors of De piscibus are commendably attentive to variants in the text of Pliny, but they missed this one. As it happens, they are silent about the others underlined above as well, because the compiler of the Hortus excised most of Vincent's problem-filled extract. In short, the information in the critical apparatus of Pliny's text is necessary to understand the passage's medieval progeny.

\section{Getting from here to there}

I have focused here on showing the value of the finest of fine-grained information about our texts. But that is me remaining in my philological

${ }_{53}$ I supply the notes from both editions here since the editors disagree on what to report. The Teubner edition has a negative apparatus, so lemmata are sometimes implicit, as in the entry on mutant. 
comfort zone. If I look up from page and screen and stare off into space for a moment, I can glimpse the possibility that compilation methods might be one of the areas of 'distant reading' that could enlist texts from a wide range of periods and literatures. For example, it might be interesting to investigate the concept of authority: how authoritative are authorities such as Pliny for the encyclopedists who cite them? How important is the name of the authority? And is this name-dropping or scholarly argument? Another bigger-picture topic is the nature of argumentation in encyclopedic works. Does an accumulation make an argument, and if so, how does it work? In other words, both burrowing down and gazing up are worth doing in our mutual enterprise of bringing texts to readers.

I mentioned at the outset the capacity of editions to create links between editor and text, between scholarly generations, and between fields. The links I had in mind at that point were conceptual, but what I hope for the future of editing, is that the connections enabled by texts and editors acquire substance and durability: that they become infrastructure, so to speak. Not floating piers like those of the lovely installation on Lago d'Iseo shortly before the 2016 Ars edendi conference, which were in the water for a few short weeks, but the Pont du Gard, which one can still traverse after two millenia.

\section{Appendix 1}

Passages of the Hortus sanititatis taken from the Speculum naturale of Vincent of Beauvais and derived from Pliny, $\mathrm{NH}_{9}$, with alterations by Vincent including:

(I) word order changes (underline)

(2) additions, particularly of conjunctions and particles (bold)

(3) simplineations of vocabulary and lists (outline)

(4) clarifications of meaning (italic)

(5) CHANGE of meaning (capitals)

(6) Textual variants (small caps)

HS 4.I.5 (= SN I7.29.5 > NH 9.60): Apud antiquos piscis nobilissimus habitus accipender, unus omnium squamis ad os versis contra AQUAM NANDO meat. Nullo nunc in honore est, quod quidem miror, cum sit rarus inventu. Quidam eum elopem vocant.

HS 4.2.2 (= SN I7.3I.2 > NH 9.74): Anguillae octonis vivunt annis. Durant et sine aquis diebus senis aquilone spirante, austro paucioribus. 
AT HIEMEM in exigua aqua non tolerant neque in turbida. Ideo circa Vergilias maxime capiuntur, fluminibus tum praecipue turbidis. Pascuntur noctibus. Exanimes piscium solae non fluitant.

HS 4.2.2 (= SN I7.3I.2 > NH 9.73): Porro vice pedum pinnae datae sunt binae piscibus omnino longis ut anguillis et congris.

$H S$ 4.2.3 (= SN I7.3I.2 > NH 9.I60): Anguillae scopulis se atterunt eaque strigmenta vivescunt; nec alia est earum procreatio

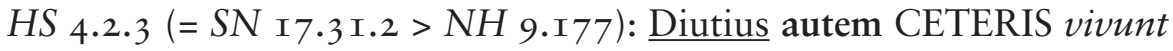
anguillae aquis exemptae

HS 4.2.3 (= SN I 7.32.3 > NH 9.I 5 5): Aculeo spinae in dorso obnoxius est ac venenosus

HS 4.4.4 (= SN I7.32.3 > NH 9.145): Aries est piscis qui grassatur ut latro: nunc grandi navium in salo stantium occultatus umbra, si quem nandi voluptas invitet expectat, nunc elato extra aquam capite piscantium cymbas speculatur, occultatusque adnatans mergit.

HS 4.I4.2 (= SN I7.34.2 > NH 9.I2): Balaenas in Gaditano oceano non ante brumam conspici tradunt, condi autem AESTATIS temporibus in quodam sinu placido et capaci, mire gaudentes ibi parere; hoc scire orcas, infestam his beluam et cujus imago nulla representatione alia possit exprimi quam carnis immensae dentibus truculentae.

HS 4.I4.2 (= SN I7.34.2 > NH 9.13): Irrumpunt ergo in secreta vitulosque illarum aut fetas vel etiamnum gravidas morsu laceramt incursuque ceu Liburnicarum rostris fodiunt. Illae vero ad flexum immobiles, ad repugnandum inertes ac pondere suo oneratae, tunc quidem 通 utero graves pariendive poenis invalidae, solum auxilium noverunt in altum perfugere seque toto oceano defendere. Econtra orcae laborant occurrere seque opponere et CAVATIS angustiis trucidare, in vada urgere, saxis illidere. Spectantur hujusmodi proelia ceu ipso mari sibi irato, nullis in sinu ventis, fluctibus vero ad anhelitus ictusque quantos nulli turbines volvunt.

HS 4.I4.2 (= SN I7.34.2 > NH 9.I6): Ora balaenae habent in frontibus ideoque summa aqua ANNATANTES in sublime nimbos efflant.

HS 4.I4.2 (= SN I7.34.2 > NH 9.19): Balaenis branchiae non sunt, sicut nec delphinis. Haec duo genera fistulis spirant quae ad pulmonem pertinent, balaenis a fronte, delphinis a dorso. 
HS 4.I4.3 (= SN I7.34.2 > NH 9.4I): Quae pilo vestiuntur animalia pariunt, ut pristis balaena vitulus.

HS 4.20.4 (= SN I7.I04.4 > NH 9.46): 通 Gange Indie Statius Sebosus haud modico miraculo affert vermes branchiis binis, Lx cubitorum, ceruleos, qui nomen a facie traxerunt; his tantas esse vires ut elephantos ad potum venientes mordicus comprehensa manu abstrahant in profundum.

$H S$ 4.22.I (= SN I7.44.I > NH 9.I02): Concharum genera firmioris sunt testae, in quibus magna varietas apparet ludentis naturae, tot colorum differentiae, tot figurae.

HS 4.22.I (= SN I7.44.I > NH 9.I06): inter quas PRINCIPATUM tenent margaritae.

HS 4.23.I (= SN I7.45.I > NH 9.IOI): Cochleae aquatiles terrestresque sunt exerentes se domicilio, binaque ceu cornua protendentes contrahentesque. Oculis carent, ideoque corniculis earum praetentant iter.

HS 4.24.2 (= SN I7.46.I > NH 9.73): Conger est piscis longus ut anguilla vel murena, flexuoso inpulsu corporis ita mari utens natando ut serpens terra rependo.

HS 4.24.2 (= SN I7.46.I > NH 9.I 85 ): Conger et murena mutuo odio flagrant, caudam inter se praerodentes.

HS 4.24.2 (= SN I7.46.I > NH 9.57): Congri mensibus hiemis jacent in speluncis conditi; nec capiuntur nisi diebus AESTATIS.

HS 4.24.2 (= SN I7.46.I > NH 9.73): Pinnae, quae vice pedum datae sunt piscibus, binae sunt omnino longis, ut anguillis et congris.

HS 4.24.2 (= SN I7.46.I > NH 9.87): Polippum sua rodere brachia falsa opinio est

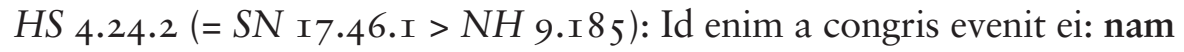
polippum lacerant congri. Polippum vero locusta pavet, locustam conger.

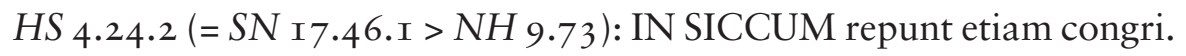
*HS 4.26.3 (= SN I7.II4.3 > NH 9.82): Draco marinus captus et immissus in arenam cavernam sibi rostro mira celeritate excavat. 


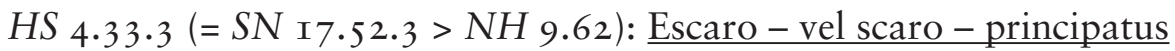
nunc datur, qui solus piscium ruminare dicitur herbisque vesci, non aliis piscibus.

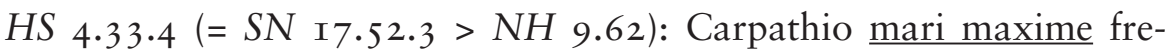
quens, promontorium Troadis Lectum numquam sponte transit. Inde autem advectos A TIBERIO CLAUDIO PRINCIPE OPTATUS ELIPERTUS, praefectus classis, inter Ostiensem et Campaniae oram sparsos disseminavit. Quinquennio fere cura est adhibita ut capti redderentur mari. Postea frequentes inveniuntur in litoribus Italiae, non ante ibi capti.

HS 4.36.3 (= SN 17.49.4 > NH 9.79): HUNC ARBITRATUR ARISTOTELES PEDES HABERE ITA posita pinnarum similitudine.

HS 4.39.3(= SN I7.54.3 > NH 9.8I): Ficis est piscis qui colorem suum mutat : reliquo tempore candida, vere autem varia. Eadem sola piscium ex alga midum fagit' atque in ipso nido parit.

HS 4.40.4 (= SN I7.55.4 > NH 9.54): Est parvum animal scorpionis effigie, aranei magnitudine; hoc se et thinno et ei qui vocatur gladius, CEREBRO delphini magnitudinem EXCEDENS, sub PINNO aculeo affigit tantoque dolore infestat ut NAVES saepenumero exiliant.

HS 4.40.6 (= SN 17.55.6 > NH 9.58): Quidam enim pisces aestate impatientes sexagenis diebus mediis latent fervoribus, ut glancus et azellus.

HS 4.43.2 (= SN 17.57.2 > NH 9.49): Amiam sive hamiam vocant piscem cujus incrementum diebus singulis intelligitur. Cum thinnis haec et pelamides in Pontum intrant gregatim ad dulciora pabula, cum suis quaeque ducibus.

HS 4.49.2 (= SN I7.6I.4 > NH 9.155): VENENA DIRA NON CESSANT IN LEPORE. Qui in Indico mari, etiam tactu pestilens, vomitum dissolutionemque stomachi protinus creat.

HS 4.5 I.2 (= SN I7.I I9.2 > NH 9.83): Loligo est piscis mollis sanguine carens sicut et sepia. Caput habet etiam, sicut et sepia, inter ventrem et pedes.

HS 4.5I.3 (= SN I7.II9.2 > NH 9.83): Sepiae et loligini pedes duo ex his longissimi sunt et asperi, quibus ad ora cibos admovent et in fluctibus se velut anchoris stabiliunt. 
HS 4.5 I.3 (= SN I7.II9.2 > NH 9.84): Loligo etiam volitat, extra aquam se efferens.

HS 4.5 I.4 (= SN I7.II 9.2 > NH 9.I64): Sepia quidem in terreno parit inter arundines ac in alto CONSERVATA OVA edunt loligines.

HS 4.5 I.5 (= SN I7.II9.2 > NH 9.1 58): Item loligines, sicut et sepiae, coeunt linguis, brachia inter se componentes et in contrarium natantes; ore quoque pariunt.

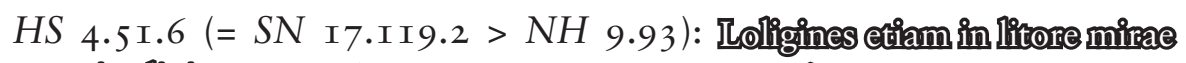
magnitudilinis sunt, sed in mari nostro quinque बubitorum. Nec ossa nec spinas habent.

HS 4.52.3 (= SN I7.63.2 > NH 9.95): Locustae pisces crusta fragili muniuntur; in eo genere quod caret sanguine latent mensibus quinis. Similiter et cancri, qui eodem tempore occultantur.

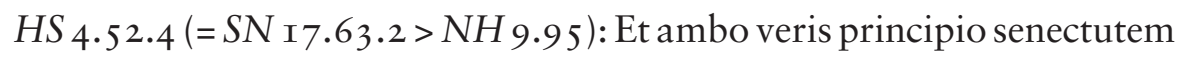
more anguium exuunt renovatione tergorum. Cetera in undis natant; locustae reptantium more fluitant

HS 4.52.5 (= SN I7.63.2 > NH 9.95): Si nullus ingruat metus, recto meatu, cornibus, quae sunt rotunditate praepilata, ad latera porrectis, et eisdem erectis in pavore oblique in latera procedunt. Cornibus inter se dimicant.

HS 4.52.6 (= SN 17.63.2 > NH 9.96, 9.4): Vivunt autem hujusmodi locustae in petrosis locis. In Indico mari locustae quatema oubita implent.

HS 4.52.7 (= SN I7.63.2 > NH 9.185): Polippum in tantum locusta pavet ut, si juxta viderit, omnino moriatur. Locustam quoque conger inimicus lacerat.

HS 4.54.3 (= SN I 7.65.3 > NH 9.57): Praegelidam hiemem omnes sentiunt pisces, sed maxime qui lapidem in capite existimantur habere, ut lupi ępageil. Cumque asperae fuerint hiemes, multi capiuntur caeci.

HS 4.54.3 (= SN I 7.65.3 > NH 9.6I): Luporum vero sunt laudatissimi qui appellantur lanati, candore mollitiaque carnis.

HS 4.54.3 (= SN I 7.65.3 > NH 9.168-69): Meliores sunt lupi in amne Tiberi inter duos pontes quam alibi. 
HS 4.54.4 (= SN 17.65.3 > NH 9.162): Piscium lupus bỉs 迎 anno parie.

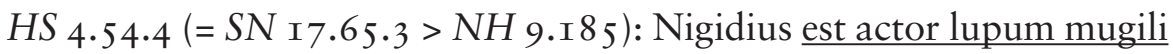
caudam praerodere eosdemque mensibus statis concordes esse.

HS 4.55.5 (= SN I7.66.5 > NH 9.82): Milvus SUBIT IN SUMMA MARIA, PISCIS EX ARGUMENTO APPELLATUS LUCERNA: LINGUAQUE IGNEA PER OS EXERTA TRANQUILLIS NOCTIBUS RELUCET.

HS 4.55.6 (= SN I7.66.5 > NH 9.82): Attollit e mari sesquipedalia fere cornua AB HISQUE NOMEN TRAXIT.

$H S$ 4.56.2 (= SN I 7.67.2 > NH 9.59): Mugilum natura ridetur, in metu capite abscondito totos se बe्culltare credentium. Iisdem tamen tanta FACILITAS ut in Phoenice et Narbonensi provincia, coitus tempore, e vivariis marem, linea longinqua per os ad branchias religata, emissum in mare eodemque linea retractum feminae sequantur ad litus rursusque feminam mares partus tempore.

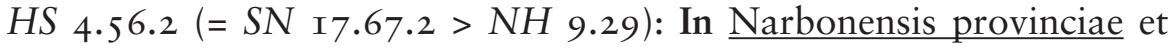
in Nemausiensi agro, stagno scilicet LATERNA appellato, ubi HOMINES DELPHINI SOCIETATE ET MUGILUM piscantur.

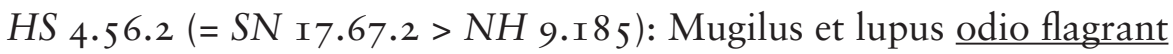
mutuo.

HS 4.56.2 (= SN I 7.67.2 > NH 9.54): Mugiles aliorum piscium vim timentes, super naves exiliunt et tam praecipuae velocitatis sunt ut transversa navigia interim SUPERJACTENT

HS 4.57.3 (= SN I7.74.3 > NH 9.186): Amicitiae sunt exempla musculus et balaena: quandoque praegravi superciliorum pondere obrutis ejus oculis, infestantia magnitudinem in vada praenatans demonstrat oculorumque vice fungitur.

HS 4.57.5 (= SN I 7.74.5 > NH 9.63): Mustelae pisces mensae deputantur; quas inter Alpes lacus Rethiae Bigrantinus aemulas MURENIs generat.

HS 4.58.3 (= SN 17.73.3 > NH 9.160): Animalia marina quae sunt durae testae, ut murices aut purpurae, salivario lentore proveniunt, sicut acescente humore culices, atque spuma maris incalescente cum admissus est imber. 


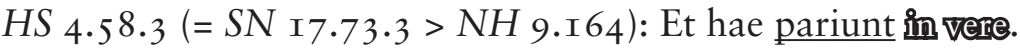

HS 4.59.2 (= SN I7.7 I.2 > NH 9.72, 9.40): 迎urena estpịiscis longus, molli oute intectus.

HS 4.59.2 (= SN I 7.7 I.2 > NH 9.57): Hileme latet nee capilitur nisi diebus AESTATIS, siout बonger ę đmnes saxatîles.

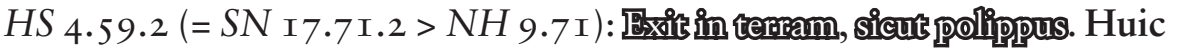
aemula et mustela.

HS 4.59.2 (= SN I7.7I.2 > NH 9.72): Quibusdam piscibus datae sunt pinnae vice pedum, quibusdam vero nullae sunt, ut murenis, quibus nec branchiae: haec flexuoso impulsu corporum ita mari utuntur, ut serpentes terra; in sicco quoque repunt.

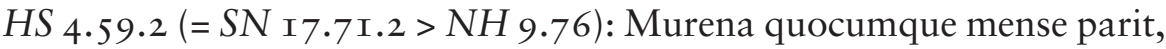
cum ceteri pisces STATUTO tempore pariant. Ova ejus citissime crescunt. In sicco litore elapsas vulgus coitu serpentium impleri putat.

$H S$ 4.63.2 (= SN I7.75.2 > NH 9.88): Nautilos, qui ab aliis vocatur pompilos, inter praecipua miracula maris computatur. Nam supinus in summa aequorum pervenit, ita se paulatim subrigens ut, emiss $a$ per fistulam aqua, velut exoneratus sentina facile naviget. Postea, prima duo brachia retorquens, membranam inter illa mirae tenuitatis extendit: qua velificante in auras, ceteris brachiis subremigans, media cauda ut gubernaculo se dirigit. Ita vadit alto, Liburnicarum gaudens imagine, si quid pavoris interveniat, hausta se mergens aqua.

HS 4.66.3 (= SN I7.75.2 > NH 9.143): Silicea testa inclusis fatendum est nullum inesse sensum, ut ostreis.

HS 4.66.3 (= SN I7.76.5 > NH 9.I60): Putrescente limo proveniunt ac spuma circa navigia diutius stantia defixosque palos et ligna. Nuper compertum in ostrearia humorem fetificum effluere in modum lactis.

$H S$ 4.67.3 (= SN I7.78.3 > NH 9.57): Omnes quidem pisces praegelidam hiemem sentiunt, sed maxime qui lapidem habere in capite aestimantur, ut lupi ępagio Cumque asperae fuerint hiemes, multi ex eis caeci capiuntur, sicut de lupo marino dictum est superius.

HS 4.67.7 (= SN I7.78.6 > NH 9.160): Pectines sponte naturae arenosis proveniunt.

HS 4.70.I (= SN I7.79.I > NH 9.I42-43): Pinna est piscis concharum generis. Nascitur in limosis, subrecta semper nec umquam sine 
comite, quem pinnocherem vocant, alii pinophilacem, id est squilla parva, alibi cancer, dapis assectator. Pandit autem se, luminibus orbum corpus intus minutis piscibus praebens. Assultant illi protinus et, ubi licentius audacia crevit, implent eam. At illa, ore compresso, quicquid concluserit exanimat partemque socio tribuit. Quo magis miror existimasse quosdam aquatilibus nullum inesse sensum.

HS 4.74.I (= SN I7.82.I-2 > NH 9.I26): Purpuras autem vivas capere contendunt, quia cum vita sua succum illum evomunt et majoribus quidem conchis detracta concha auferunt, minores vero cum testis frangunt, ita demum rorem eum EXCIPIENTES TYRII.

HS 4.74.I (= SN I 7.82.I-2 > NH 9.I 28): Lingua purpurae longitudine digitali, qua pascitur perforando reliqua conchilia, tanta aculeo duritia. Aqua dulci enecantur et sicubi FLUMINI IMMERGUNTUR alioquin captae etiam diebus quinquagenis vivunt saliva sua.

HS 4.77.I (= SN 17.86.I> NH 9.72): Rumbus est piscis planus, sicut passer et solea. Hi a passeribus tantum situ corporum differunt. Dexter hic RESUPINATUs est illis, passeri levus.

HS 4.84.3 (= SN I 7.84.3 > NH 9.78): Squatina est ex piscium genere qui pro spina cartilaginem habent. Omniaque talia CARNOSIORA sunt, et supina vescuntur.

HS 4.84.3 (= SN I7.84.3 > NH 9.I6I): Diversa piscium genera non coeunt insimul praeter squatinam et ranam. Ex quibus nascitur piscis parte priori ranae similis. Et nomen ex utroque compositum apud Graecos trahit.

HS 4.84.3 (= SN I 7.84.3 > NH 9.1 62): Piscium quidam ter in anno pariunt, quidam bis, vere et autumno; ex planis sola squatina bis, autumno occasuque Vergiliarum.

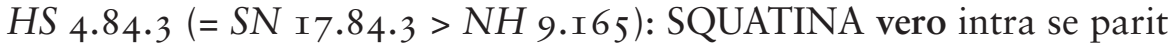
ova praemollia in alium locum uteri transferens ibique excludens. Simili modo et omnia quae appellavimus cartilaginea. Ita fit ut sola piscium et animal pariant et ova concipiant.

HS 4.86.I (= SN I7.88. I > NH 9.I 45): Scolopendrae marinae, terrestribus similes, quas centipedes vocant, hamo devorato omnia interanea evomunt donec hamum egerant, deinde resorbent.

HS 4.86.4 (= SN 17.88.4 > NH 9.99): Cancri mortui in scorpiones figurantur in sicco. 
$H S$ 4.90.I (= SN I 7.95.I $>$ NH 9.I 83): $\underline{\text { Stellam in mari sapientia claros }}$ autores video mirari. Cujus figura haec est, parva admodum caro intus, extra duriore callo. Huic tam igneum fervorem esse tradunt ut omnia in mari contacta adurat, omnem cibum statim peragat.

HS 4.92.3 (= SN I 7.96.2-3> NH 9.78): Torpedo, sicut et squatina, est ex genere piscium qui cartilaginem habent pro spina. Omniaque talia CARNOSIORA sunt et supina vescuntur.

HS 4.92.3 (= SN 17.96.2-3 > NH 9.165): Torpedo ova intra se parit praemollia, in alium uteri locum transferens, ibique excludens. OCTOGENOS HABET FETUS.

HS 4.92.3 (= SN I7.96.2-3 > NH 9.I43): Novit torpedo vim suam, ipsa non torpens mersaque in limo se occultat.

HS 4.102.3 (= SN I7.99.2 > NH 9.146): Urtica noctu vagatur NOCTUQUE MUTATUR. Vis ejus pruritu mordax eadem quae terrestris urticae.

HS 4.102.6 (= SN I7.99.4 > NH 9.145): Vulpes marinae in periculo capturae glutiunt non tantum hamum sed amplius usque ad infirma lineae quae facile praerodant.

\section{Bibliography}

\section{Editions}

Pliny:

Mayhoff, Karl. I892-1909. C. Plini Secundi Naturalis historiae libri XXXVII. 6 vols. Leipzig.

de Saint-Denis, E., ed. I955. Pline l'ancien, Histoire naturelle. Livre IX. Paris. de Saint-Denis, E., ed. 1966. Pline l'ancien, Histoire naturelle. Livre XXXII. Paris.

Vincent of Beauvais:

Vincent of Beauvais, Bibliotheca mundi: Vincentii Burgundi ... speculum quadruplex, naturale, doctrinale, morale, historiale. Vol. I (Douai, I624).

Vincentius Belvacensis, Speculum naturale, version SM trifaria (I624). http:// sourcencyme.irht.cnrs.fr/encyclopedie/voir/I33 (accessed I7 April 2020).

Hortus sanitatis:

Jacquemard, C., et al., eds, L'Hortus sanitatis: Livre IV: Les poissons (Caen, 20I3). https://www.unicaen.fr/puc/sources/depiscibus/ (accessed I7 April 2020). 
Secondary literature:

Albrecht, E., De ontstaansgeschiedenis en de compilatie van het Speculum Naturale van Vincent van Beauvais († I 264) (The Genesis and Compliation of the Speculum Naturale of Vincent of Beauvais ( ${ }^{\dagger}$ I 264)), 2 vol. (Diss. Leuven, 2007; non vidi).

Andrée, Alexander, 'Editing the gloss (later Glossa ordinaria) on the Gospel of John: A structural approach,' in Göransson et al., eds, pp. 2-2 I.

Borst, Arno, Das Buch der Naturgeschichte: Plinius und seine Leser im Zeitalter des Pergaments, 2nd ed. (Heidelberg: Winter, I995).

Buard, P.-Y., Modélisation des sources anciennes et édition numérique (PhD diss. Université Caen, Normandie, 20I 5 ).

Bucossi, Alessandra, 'The use of an apparatus collationum fontium in the critical edition of a patristic anthology,' in Göransson et al., eds, pp. 34-54.

Crostini, Barbara, 'Editing a Greek catena to the Psalter from a single illuminated manuscript: Vaticanus graecus 752,' in Göransson et al., eds, p. 55-7I.

De Vos, Ilse, et al. eds, 'L'art de compiler à Byzance: La lettre $\Gamma$ du Florilège Coislin', Byzantion 78 (2008): I 59-223.

De Vos, Ilse, et al. eds, 'La lettre B du Florilège Coislin: editio princeps', Byzantion 80 (2010): 72-120.

Draelants, I., avec la collaboration de E. Kuhry. 20IO. 'Les sources mises en ligne par des médiévistes à l'Université de Nancy. En particulier, le programme "Sourcencyme" de corpus annoté des textes encyclopédiques latins et de leurs sources,' in Th. De Hemptinne and J.-L. De Paepe, eds, Actes de la Journée d'étude 'Digital Edition of Sources in Europe: Achievements, (juridical and technical) Problems and Prospects', organisée aux Archives générales du Royaume à l'occasion des I75 ans de la Commission Royale d'Histoire (Bruxelles: Bulletin de la Commission royale d'Histoire, 2010), pp. 49-78.

Dunning, Andrew, 'Networking Scholarly Editions' (7 May 20I5). https:// medium.com/@dunning/networking-scholarly-editions-ec38fdefefof (accessed I7 April 2020).

Franklin-Brown, M., Reading the world: Encyclopedic writing in the scholastic age (Chicago: Chicago University Press, 2012).

Gauvin, B., et al., 'Emprunts, compilation, et réécriture dans l'Hortus sanitatis,' Schedae prépublication I (20II), I-2I.

Göransson, E. et al., The Arts of Editing Medieval Greek and Latin: A Casebook, ed. by G. Iversen, B. Crostini, B.M. Jensen, E. Kihlman, E. Odelman and D. Searby. Studies and Text 203 (Toronto: PIMS, 20I6). 
Göransson, E., 'Connecting the case studies: Editorial methods and the editorial circle model', in Göransson, E. et al. eds, pp. 400-429.

Hicks, Andrew, 'Editing medieval commentaries on Martianus Capella's De nuptiis Philologiae et Mercurii: A synopsis traditionis,' in Göransson et al., eds, pp. I39-58.

Jacquemard, C., et al., 'L'Hortus sanitatis: Transmission et réorganisation de la matière encyclopédique au XV siècle', Revue d'histoire des textes, n.s. VII (2012): 353-369.

Jacquemard, C., and P.-Y. Buard, 'Le projet Ichtya entre édition critique et constitution de corpus', Schedae, prépublication I 4, fascicule I (20I I), I 39-I 52.

Jeffreys, E., and M. Jeffreys, eds, Iacobi Monachi Epistulae. Corpus Christianorum Series Graeca, 68 (Turnhout: Brepols, 2009).

Jeffreys, E., 'Tapestries of quotation: The challenges of editing Byzantine texts', in Ars edendi lecture series, Volume II, ed. by A. Bucossi and E. Kihlman. Acta Universitatis Stockholmiensis: Studia Latina Stockholmiensia LVIII (Stockholm: Stockholm University, 20I 2), pp. 35-6I.

Lusignan, Serge, Préface au Speculum maius de Vincent de Beauvais: Réfraction et diffraction (Montreal: Bellarmin, I979).

Macé, C, 'Rules and guidelines in book series and their impact on scholarly editions', in Göransson, E. et al. eds, pp. 248-266.

Mulchahey, Marian Michèle, 'First the bow is bent in study': Dominican education before I350. Studies and Texts I32 (Toronto: PIMS, I998).

Näf, B., Roberti Crikeladensis Defloratio Naturalis Historie Plinii Secundi (Bern: Peter Lang, 2002).

Paulmier-Foucart, M., and M.-C. Duchenne, 'Vincent de Beauvais à l'Atelier,' in Cahiers de Recherches Médiévales (XIII $-X V^{e}$ s.) IV (I999), 59-74.

Paulmier-Foucart, M., and M.-C. Duchenne, Vincent de Beauvais et le Grand Miroir de monde (Turnhout: Brepols, 2004).

Paulmier-Foucart, M., and S. Lusignan, 'Vincent de Beauvais et l'histoire $d u$ Speculum Maius,' Journal des savants I990: 97-I 24.

Paulmier-Foucart, M., and S. Lusignan, eds, Lector et compilator: Vincent de Beauvais, frère prêcheur: Un intellectuel et son milieu aux XIII ${ }^{e}$ siècle (Grâne: Créaphis, I997).

Paulmier-Foucart, M., et al., eds, Vincent de Beauvais: Intentions et réceptions d'une cuvre encyclopédique au Moyen-Age: Actes du XIVe colloque de l'Institut d'études médiévales (avril I988). Cahier d'études médiévales 4 (St Laurent: Bellarmin, I990). 
Pinkster, Harm, 'The language of Pliny the elder', in T. Reinhardt et al., eds, Aspects of the language of Latin prose. Proceedings of the British Academy I 29 (Oxford: Oxford University Press, 2005), pp. 239-56.

Roy, Bruno, 'La trente-sixième main: Vincent de Beauvais et Thomas de Cantimpré,' in Paulmier-Foucart et al., eds, pp. 24I-252.

Shanzer, D., 'Editions and editing in the classroom: A report from the mines in America,' in B. Merta et al., eds, Vom Nutzen des Edierens: Akten des internationalen Kongresses zum I50-jährigen Bestehen des Instituts für Österreichische Geschichtsforschung, Wien, 3.-5. Juni 2004 (Wien: Oldenbourg, 2005), pp. 355-368.

Silvi, Christine, 'Citer Pline dans les encyclopédies médiévales: L'exemple des notices zoologiques chez Thomas de Cantimpré et Vincent de Beauvais', Archives internationales d'histoire des sciences, 6I (20I I), 27-55.

Tarrant, R. J., Texts, editors, and readers: Methods and problems in Latin textual criticism (Cambridge: Cambridge University Press, 2016).

Tounsi, Molka, et al., 'Studying the history of pre-modern zoology by extracting linked zoological data from mediaeval texts and reasoning on it,' in F. Gandon et al. eds, The Semantic Web: ESWC 2015 Satellite Events. ESWC 2015. Lecture Notes in Computer Science, vol 934I (Springer: Cham, 20I5), pp. 406-4I5.

Tounsi, Molka, et al., 'Studying the history of pre-modern zoology with linked data and vocabularies,' in Arnaud Zucker et al., eds, First International Workshop Semantic Web for Scientific Heritage at the I 2 th ESWC 2015 Conference. SW4 4 SH 2015 Semantic Web for Scientific Heritage 20I5, I June 2015 , Portorǒz, Slovenia. CEUR Workshop Proceedings. 7-I 4. http:// ceur-ws.org/Vol-I364/ (accessed I7 April 2020).

Van den Abeele, B, 'Vincent de Beauvais naturaliste: Les sources des livres d'animaux du Speculum naturale', in Lector et compilator: Vincent de Beauvais, frère prêcheur: Un intellectuel et son milieu aux XIII ${ }^{e}$ siècle, ed. by M. Paulmier-Foucart and S. Lusignan (Grâne: Créaphis, I997), pp. I 27-I 5 I.

Van den Abeele, B., Review of Jacquemard et al., eds, 2013. Scriptorium 69 (2OI5), I 82-I 83 .

Ventura, Iolanda, 'Extraire, organiser, transmettre le savoir dans les encyclopédies du Moyen Âge tardif: Albert le grand dans le Speculum naturale de Vincent de Beauvais et la Catena aurea entium d'Henry d'Herford,' in Sébastien Morlet, ed., Lire en extraits: Lecture et production des textes de l'Antiquité à la fin du Moyen Âge (Paris: Presses de l'université ParisSorbonne, 20I 5), pp. 443-464. 